\title{
Pulp and paper mill waste pollution in the Swale, a tidal channel on the east coast of England
}

\author{
R. S. Millner \\ Ministry of Agriculture, Fisheries and Food, Fisheries Laboratory; \\ Lowestoft, Suffolk, NR33 OHT, UK
}

\begin{abstract}
The effect of pulp and paper mill waste discharges in the Swale, a tidal channel on the southeast coast of England, has been studied. A pulsing tidal movement in the Swale results in effluent being trapped within the estuary for up to 20 days. This has resulted in adverse effects on the quality of the water and sediment along a substantial part of the estuary with the greatest effect occurring east of the mill in the direction of the residual current. A reduction in the dissolved oxygen concentration occurred along a 13-km stretch of the estuary with mean values falling to $53 \%$ saturation near the mill. High levels of organic matter in the sediment reflect the deposition of material from the mill effluent stream and loss on ignition values of up to $12 \%$ were found east of the mill, falling to $5 \%$ within $4 \mathrm{~km}$ northwest of the mill. The macrofauna of the intertidal mudflats was typical of a stressed environment with a low number of species and with a few being represented by large numbers of individuals. The dominant species was the sabellid polychaete Manayunkia aestuarina which reached peak numbers of over 1.5 million $\mathrm{m}^{-2}, 1.5 \mathrm{~km}$ east of the mill. An increase in the total biomass near the mill is thought to be associated with organic enrichment from the mill wastes.
\end{abstract}

\section{INTRODUCTION}

The chemical pulping of wood produces a highly coloured effluent which contains a mixture of waste organic products derived from the wood, together with the waste chemicals used in the pulping process. The effects of the discharge of this material into the marine environment have been described for a number of bays and inlets in boreal waters (Bagge, 1969; Pearson, 1970, 1971a, b, 1975; Rosenberg, 1972, 1973a, b; Leppäkoski, 1975; Poole et al. 1977). Among the most noticeable effects is an increase in the organic loading of the receiving waters which results in a high oxygen demand exerted on both the water column and sediment. The deposition of organic matter onto the sediment has usually been associated with a change in the structure of the benthic community; in some areas discolouration of the water column and inhibition of phytoplankton growth has also been observed (Parker \& Sibert, 1973; Stockner \& Cliff, 1976).

The purpose of the study reported here was to assess the effect of the mill effluents on the Swale environment. This paper briefly summarises some of the main ecological findings obtained between 1971 and 1973. 


\section{STUDY AREA}

The Swale is a tidal channel separating the Isle of Sheppey from the Kent mainland on the southeast coast of England (Fig. 1). The northwestern half of the Swale forms a narrow and relatively deep channel with a shoreline of exposed geological clay where tidal scour is strongest. Deep, soft mud deposits characterise the sediments in the middle reaches of the Swale and as the channel widens again eastwards towards Whitstable Bay, the sediments become increasingly sandy until on the Whitstable Flats, they consist of fine sand, mud and shell. The area surrounding the Swale has remained largely

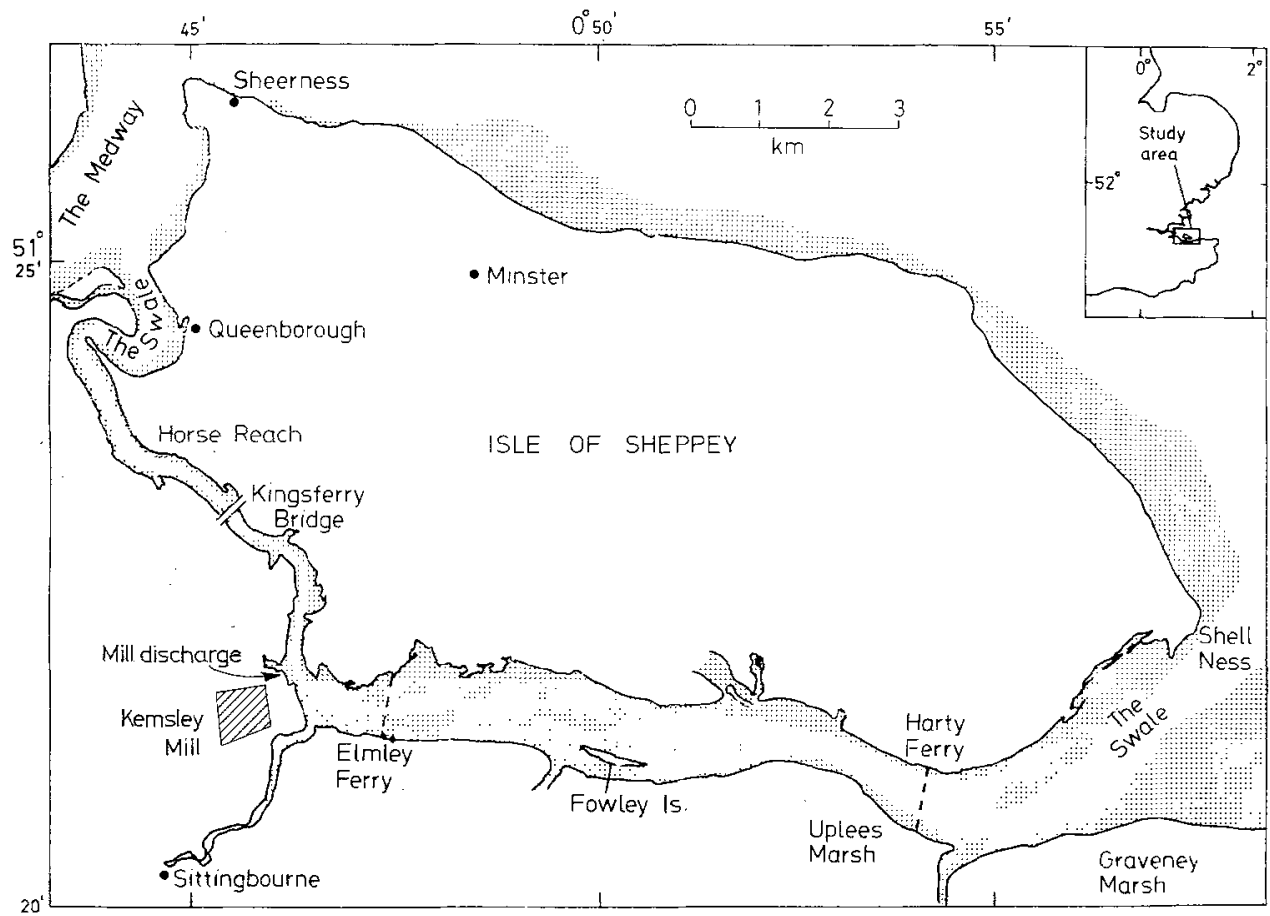

Fig. 1. The Swale showing the position of the paper mill discharge at Kemsley (southeast England)

unspoilt with little housing and industrial development. However, the towns of Queenborough on the Isle of Sheppey together with Sittingbourne and Faversham on the Kent mainland release industrial and sewage effluents into the creeks which drain into the Swale. In addition pulp and paper mill effluents have been released into the Swale for over 90 years and at present these effluents form the most important polluting inputs to the Swale, amounting to nearly $94 \%$ of the total biological oxygen demand (BOD) load (Fig. 2).

The movement of the tidal streams in the Swale has a profound influence on the quality of the water within the estuary since it determines the amount of water available to dilute each discharge of effluent and also affects the rate at which effluent is flushed through the Swale. The basic pattern of tidal movement has been described by Evans\& Newell (1957) and is dominated by the flow of water in the outer Thames estuary. As the tide floods in the Thames, water moves around the Isle of Sheppey and enters the 
Swale at both its northern and eastern entrances. The confluence of the opposing tidal streams is not well defined but lies somewhere within the central region of the Swale. After the period of high water (HW) slack in the estuary, water continues to flow into the Swale past the northern entrance while the tidal stream in the eastern Swale has reversed direction and begun to ebb to the east. Consequently, for a period of about $2 \mathrm{~h}$ both tidal streams move in an easterly direction through the Swale. The result of this

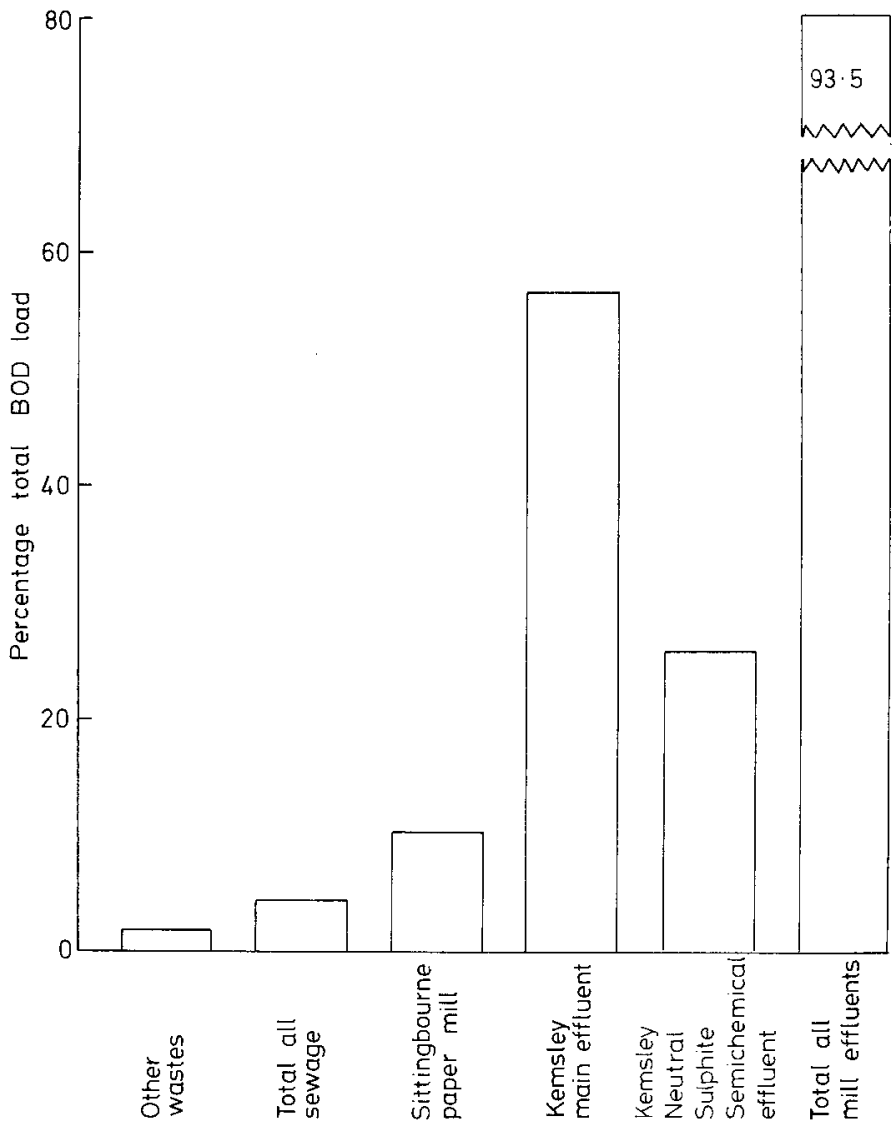

Fig. 2. Amount of pollutants discharged into the Swale as a percentage of the total BOD load

uneven tidal flow is to create an easterly residual movement of water through the Swale. Finally, as the flow of water from the north slackens, the stream reverses direction and the ebb streams now flow in opposite directions until low water.

The effect of the tidal movement on mill effluents, which are discharged for a $2 \mathrm{~h}$ period preceding each HW near the middle of the Swale, is thus initially to push the effluent in an easterly direction. However, the tidal stream is not sufficiently strong to push the effluent out of the estuary on a single tide and as a result it is carried back into the estuary by the next flood tide. Each effluent patch then pulses back and forward within the Swale gradually being carried eastward by the residual water movement until 
eventually it is diluted and carried out of the estuary. The time taken for effluent to leave the Swale will vary with the spring and neap tidal cycle but may be between 5 and 20 days (J. W. Talbot, personal communication).

\section{METHODS}

Salinity and dissolved oxygen concentrations of the water column were measured using a standard salinity-temperature bridge and dissolved oxygen meter. Sediment parameters were determined by analysis of core samples taken manually from around the low water and mid-tide regions of the intertidal mudflats. The organic matter in the sediments was determined by combustion of dried material in a furnace at $550^{\circ} \mathrm{C}$, and an assessment of fibre deposition was made from the plant material retained on an $0.5-\mathrm{mm}$ sieve after removal of the benthos. Particle size analysis was carried out according to methods described by Holme and McIntyre (1971). Benthos was collected at approximately three-monthly intervals for a period of two years by taking ten 5 -cm diameter core samples at each site and sieving the material through an 0.5-mm sieve. Biomass was estimated as ash-free dry weight of representative samples. Samples were taken regularly at four stations: Kingsferry Bridge, the mill outfall, Elmley Ferry and Harty Ferry (see Fig. 1).

\section{RESULTS}

The salinity of the water in the Swale was determined largely by the inflow of water from the Thames and Medway estuaries, although local variations in salinity occurred where small creeks of fresh water drained into the Swale. The mean salinity ranged from $28.5 \%$ near the mill outfall (for position see Fig. 1) to around $31 \%$ at the northern and eastern entrances to the Swale.

\section{Effect of mill effluent on water and sediments}

The mean dissolved oxygen concentration at both high and low water along an approximately 13- $\mathrm{km}$ stretch of the Swale is shown in Figure 3. To the northwest of the mill, the levels of dissolved oxygen were usually high (85-90\% saturated) but dropped steadily to reach a minimum close to the mill outfall. After an initial recovery east of the mill the concentration of oxygen was progressively reduced as the effluent which was trapped within this region utilized the oxygen in the water column. In the most easterly section of the estuary, more than $10 \mathrm{~km}$ from the mill outfall, the dissolved oxygen concentration increased again under the influence of unpolluted water moving into the Swale from Whitstable Bay.

The sediments east of the mill were affected by pulp wastes to a greater extent than those northwest of the mill, reflecting the predominantly easterly movement of effluent. Thus the level of organic matter in the sediment measured in terms of the weight loss on ignition (LOI) varied from a mean value of nearly $12 \%$ east of the mill to $5 \%$ within 4 $\mathrm{km}$ northwest of the mill. East of the mill LOI values remained high for over $9 \mathrm{~km}$ from the mill outfall and showed a marked drop only when the nature of the sediment changed from fine mud to muddy sand. The distribution of fibre in sediment samples 


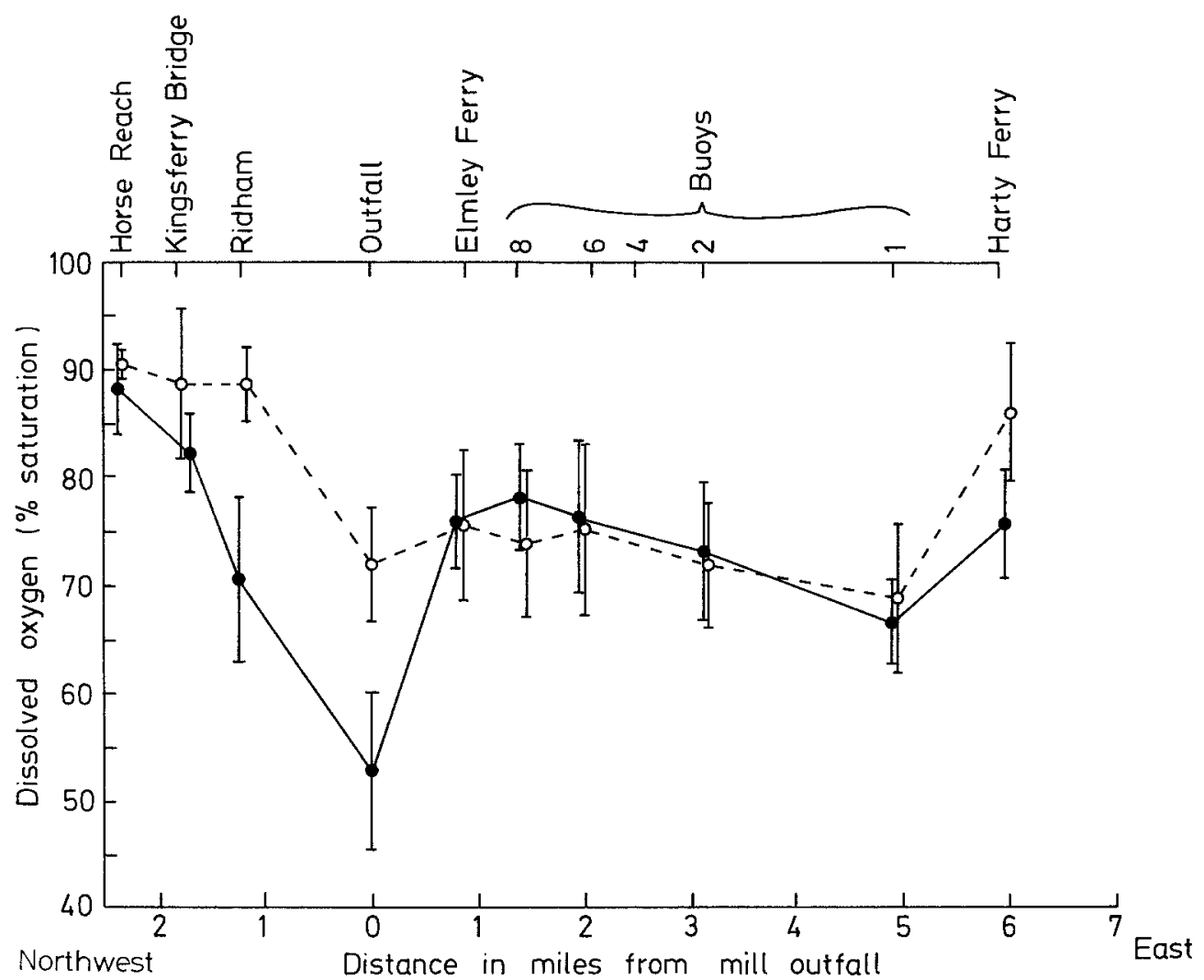

Fig. 3. Dissolved oxygen concentrations in the Swale at high water (solid line) and low water (broken line). Vertical bars indicate standard error of the mean $\times 2$

showed a similar pattern (Table 1). Although both pulp fibre and natural plant remains were present in the sediments throughout the Swale, the heaviest deposition of pulp fibre occurred east of the mill and at one station made up $94 \%$ of the total fibre load.

The sediment types at the four stations sampled regularly were similar. The median particle size of the surface samples varied from 4.1-5.2 $\varnothing(0.027-0.052 \mathrm{~mm})$ which corresponds to coarse silt particles. Measures of the frequency distribution of the particles indicated that the samples were well sorted with most of the particles lying within a few size ranges of the mean. The fact that the sediments were similar meant that, in the absence of pre-discharge studies, comparisons on the effects of mill wastes on the benthos at each station could be made with greater confidence.

\section{Effect of mill effluents on the benthos}

The results of the mid-tide samples taken over a two-year period are summarised in Table 2 which gives the number of individuals and biomass of the main taxa at each station, averaged over the sample period. Both the numbers of individuals $\mathrm{m}^{-2}$ and the biomass $\mathrm{m}^{-2}$ were highest at Elmley Ferry, approximately $1.5 \mathrm{~km}$ east of the mill outfall, 
Table 1. Dry weight of fibre extracted from sediment samples in the Swale together with standard deviations of the mean

\begin{tabular}{|c|c|c|c|c|c|}
\hline & Localities & $\begin{array}{c}\text { Total fibre } \\
\text { wt }\left(\mathrm{g} 0.1 \mathrm{~m}^{-3}\right)^{*}\end{array}$ & SD & $\%$ paper fibre & $\begin{array}{c}\text { Paper fibre } \\
\text { wt }\left(\mathrm{g} 0.1 \mathrm{~m}^{-3}\right)^{*}\end{array}$ \\
\hline \multirow{7}{*}{ (A) } & Mid-tide & & & & \\
\hline & Horse Reach & 153 & $-{ }^{* *}$ & 30 & 46 \\
\hline & Kingsferry Bridge & 117 & \pm 7.4 & 46 & 54 \\
\hline & Mill outfall & 179 & \pm 11.5 & 88 & 16 \\
\hline & Elmley Ferry & 199 & \pm 14.2 & 89 & 177 \\
\hline & Harty Ferry & 184 & \pm 8.7 & 57 & 104 \\
\hline & Graveney Marsh & 36 & $-* *$ & 6 & 2 \\
\hline \multirow{7}{*}{ (B) } & Low water & & & & \\
\hline & Horse Reach & 112 & $-^{* *}$ & 31 & 35 \\
\hline & Kingsferry Bridge & 138 & \pm 4.3 & 19 & 26 \\
\hline & Mill outfall & 632 & \pm 59.2 & 86 & 543 \\
\hline & Elmley Ferry & 240 & \pm 13.3 & 94 & 225 \\
\hline & Harty Ferry & 296 & \pm 8.4 & 49 & 145 \\
\hline & Graveney Marsh & 46 & $-^{* *}$ & 27 & 12 \\
\hline
\end{tabular}

Table 2. Mean numbers of each species $\mathrm{m}^{-2}$ at the four stations sampled

\begin{tabular}{|lrrrr|}
\hline & $\begin{array}{c}\text { Kingsferry } \\
\text { Bridge }\end{array}$ & $\begin{array}{c}\text { Mill } \\
\text { outfall }\end{array}$ & $\begin{array}{c}\text { Elmley } \\
\text { Ferry }\end{array}$ & $\begin{array}{r}\text { Harty } \\
\text { Ferry }\end{array}$ \\
\hline Mollusca & & & & \\
Hydrobia ulvae & 2220 & 8500 & 15110 & 1920 \\
Retusa obtusa & 203 & 0 & 0 & 0 \\
Abra tenuis & 2590 & 660 & 1070 & 3310 \\
Scrobicularia plana & 64 & 66 & 0 & 0 \\
Macoma balthica & 0 & 29 & 71 & 196 \\
Mytilus edulis & 36 & 0 & 14 & 29 \\
Cerastoderma edule & 0 & 14 & 0 & 0 \\
Platyhelminthes & & & & \\
$\quad$ Procerodes ulvae & 29 & 256 & 2890 & 51 \\
Leptoplana tremellaris & 0 & 0 & 240 & 0 \\
Nemathelminthes & & & & \\
Nematodes & 6810 & 124220 & 71590 & 71170 \\
Annelida & 0 & 0 & & \\
Eteone longa & 5450 & 2740 & 310 & 3620 \\
Nereis diversicolor & 203 & 263 & 496 & 210 \\
Pygospio elegans & 124 & 0 & 28 & 87 \\
Heteromastus filiformis & 5670 & 259740 & 1529640 & 49870 \\
Manayunkia aestuarina & 27300 & 84670 & 102150 & 21720 \\
Tubificids & & & & \\
Crustacea & 550 & 54800 & 18870 & 24760 \\
Harpacticoids & & & & \\
\hline
\end{tabular}


largely because of the abundance of the sabellid polychaete Manayunkia aestuarina which accounted for over $80 \%$ of the biomass and nearly $90 \%$ of the total numbers of individuals in the sample. There was a decrease in both these measures at the outfall but here too the contribution of the smaller annelids to the total biomass was larger than that
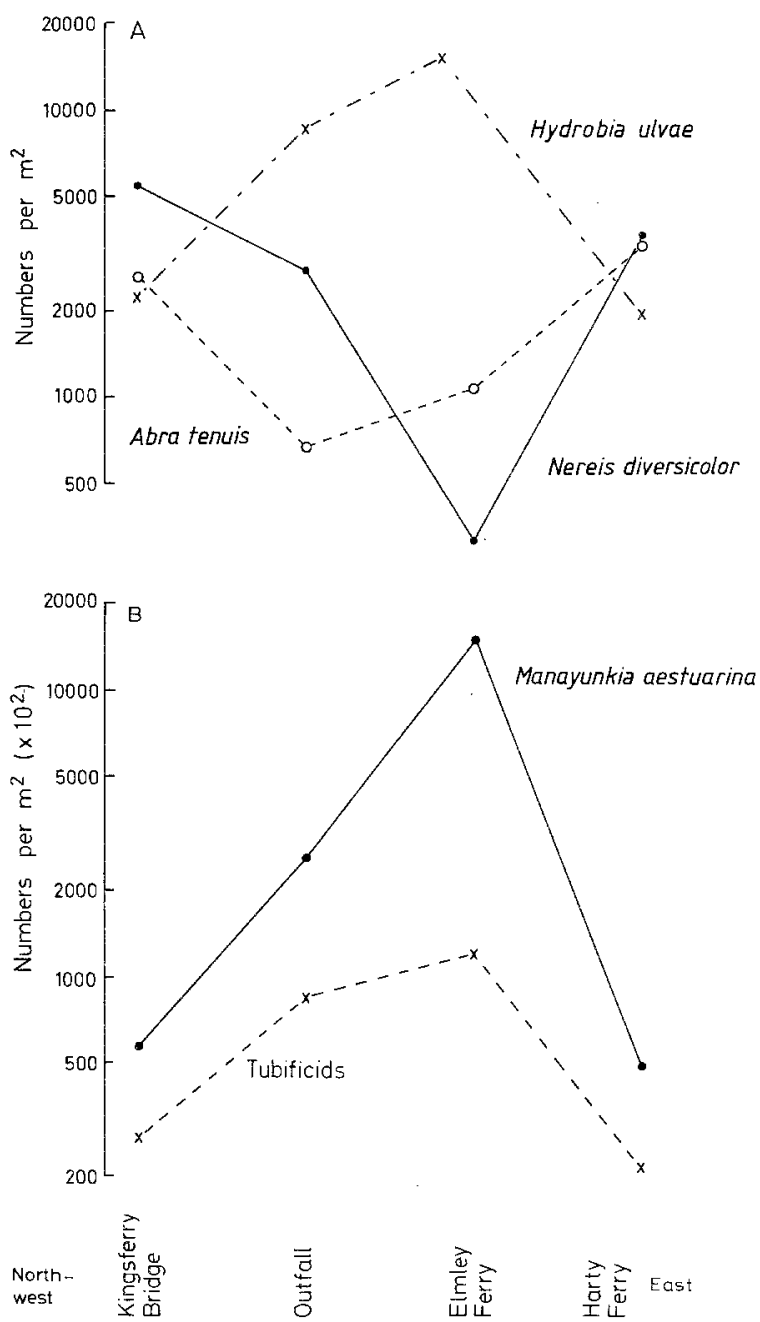

Fig. 4. The change in abundance of selected organisms in the Swate at the mill outfall-and at sites northwest and east of the mill

of any of the other groups. At the two outer stations, Kingsferry Bridge $(2.8 \mathrm{~km}$ northwest of the outfall) and Harty Ferry ( $9.5 \mathrm{~km}$ east), both the biomass and number of individuals $\mathrm{m}^{-2}$ were greatly reduced and at both stations Nereis diversicolor was the largest single contributor to the biomass.

The species composition of the benthos was essentially similar at each of the four main stations sampled (Table 3) and there was little difference between the mean 
Pulp and paper mill waste pollution

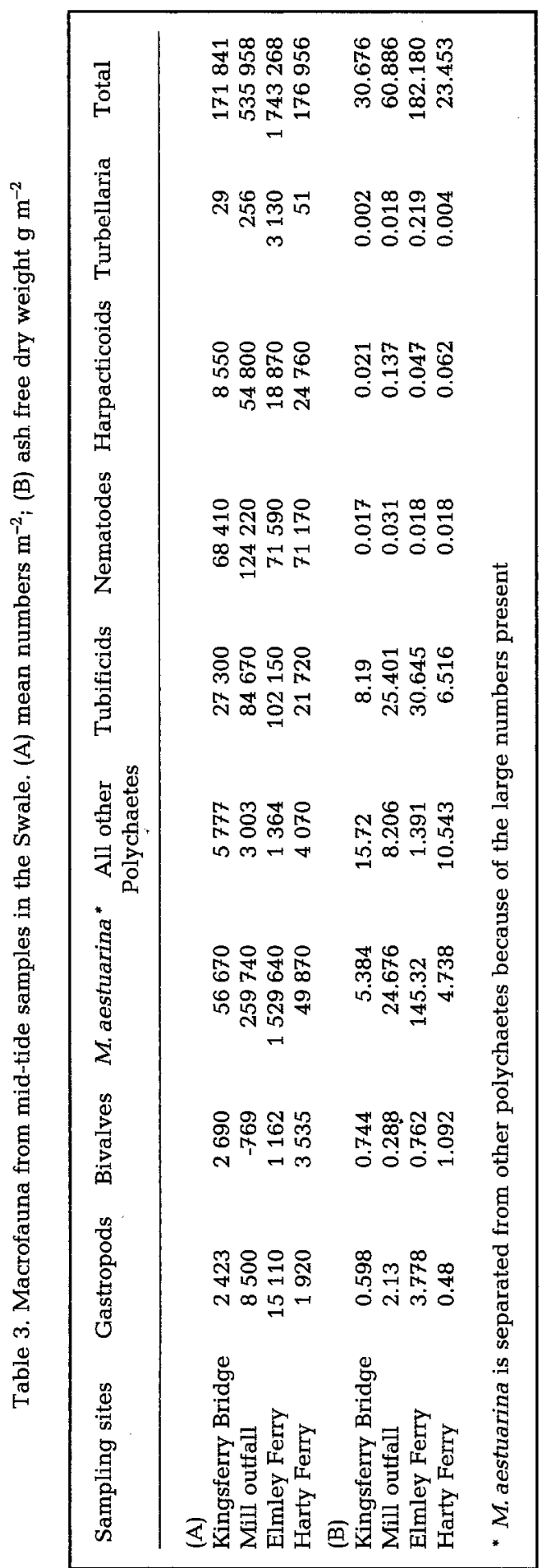


number of species at each station. Five species occurred commonly in all the mid-tide samples. These were the polychaetes Manayunkia aestuarina and Nereis diversicolor, the tubificid Peloscolex benedeni, the gastropod Hydrobia ulvae and the small bivalve Abra tenuis. Nematodes and harpacticoids were also important groups but were not adequately sampled with the $0.5-\mathrm{mm}$ mesh sieve which was used.

The main features of the distribution of the five commonest species are shown in Figure 4. At Kingsferry Bridge and Harty Ferry the numbers of $N$. diversicolor and $A$. tenuis were high in comparison to the mill outfall and Elmley Ferry. The numbers of $M$. aestuarina, tubificids and $H$. ulvae show an opposing trend with a dramatic increase at the mill outfall and at Elmley Ferry. Although the number of organisms collected in the low water samples was greatly reduced compared to the mid-tide samples, the same general relationship between abundance and distance from the outfall was evident.

\section{DISCUSSION}

The results of the study show that large areas of the Swale have been affected by the organic loading from the mill. However, the strong tidal currents have largely prevented the development of anoxic sediments and nowhere is the pollution so severe that areas are devoid of macrofauna.

There are several explanations for the low number of macrobenthic species and for the increases in abundance and biomass close to the mill. A low species number is characteristic of organically polluted areas but is also a typical feature of very fine muddy deposits. In the area of interest within the Swale, the sediments are similar in character and consist of fine well-sorted muds which contain a high proportion of particles within a limited size range. As a result the range of habitats available to macrobenthos will be reduced compared with a more mixed deposit and this will tend to limit the number of species found. A further feature of muddy sediments is the low water flow through the deposit which results in a rapid decrease in oxygen with depth. The shallow layer of aerated sediment reduces the space available for organisms living within the substrate and will tend to eliminate many deep burrowing species. The presence of shells from Mya arenaria and Scrobicularia plana indicates that these species were once abundant in the Swale, although they are now rarely found in the estuary. Organisms living close to the surface or in tubes which rise above the sediment surface will be at an advantage and this is demonstrated by the preponderance of the tube-building polychaete $M$. aestuarina close to the mill.

The fauna of soft mud deposits is already adapted to many of the features which characterise organic pollution including reduced oxygen concentrations in the water and sediments and high loss on ignition values in the sediment. The discharge of organic wastes onto the muddy sediments in the Swale will, therefore, have less effect on the benthic community than on the populations of more diverse habitats such as those described elsewhere (Pearson, 1975; Wharfe, 1975; Pearson \& Rosenberg, 1976; MCLusky et al., 1978).

The intensity of predation close to the mill is an additional factor which will affect the development of dense populations of benthic organisms under the influence of organic pollution. Reise (1977) has shown that mud communities in the German Wadden Sea which are artificially protected from intense predation are able to develop up to a 
ten-fold increase in abundance. Trawl surveys carried out in the Swale (R. G. J. Shelton \& P. J. Warren, personal communication) provide evidence that mobile predators such as flatfish and crabs are less abundant close to the mill and consequently predation might be an important factor in the development of the dense macrobenthic populations near the outfall. If commercial fish species are unable to utilise the rich source of food close to the mill, the result will be an overall decrease in the area available for feeding despite the high biomass.

\section{CONCLUSIONS}

The Swale has received discharges from pulp and paper mill wastes over the past 90 years. The most noticeable effects on the environment are depressed levels of dissolved oxygen and an increase in the organic loading of the sediment. An increase in the biomass without a significant change in the species composition of the macrobenthos at the most polluted stations reflects the ability of the soft bottom communities to tolerate a high organic input.

\section{LITERATURE CITED}

Bagge, P., 1969. Effects of pollution on estuarine ecosystems. 1. Effects of effluents from woodprocessing industries on the hydrography, bottom and fauna of Saltkallefjord (W. Sweden). Merentutkimuslait. Julk. 228, 1-129.

Evans, F. \& Newell, G. E., 1957. Tidal streams and larval dispersal at Whitstable. - Ann. Mag. nat. Hist. (Ser. 12) 10, 161-173.

Holme, N. A. \& McIntyre, A. D., 1971. Methods for the study of marine benthos. Blackwell, Oxford, 334 pp. (IBP Handbook. 16.)

Leppäkoski, E., 1975. Assessment of degree of pollution on the basis of macrozoobenthos in marine and brackish-water environments. - Acta Acad. åbo. (B) 35, (2), 1-90.

McLusky, D. S., Elliot, M. \& Warnes, J., 1978. The impact of pollution on the intertidal fauna of the estuarine Firth of Forth. In: Physiology and behaviour of marine organisms. Ed. by D. S. McLusky \& A. J. Berry. Pergamon Press, Oxford, 203-210.

Muus, B. J., 1967. The fauna of Danish estuaries and lagoons. Distribution and ecology of dominating species in the shallow reaches of the mesohaline zone. - Meddr Danm. Fisk.-og Havunders. 5 (1), 1-316.

Parker, R. R, \& Sibert, J., 1973. Effects of pulpmill effluent on dissolved oxygen in a stratified estuary. I. Empirical observations. - Wat. Res. 7, 503-514.

Pearson, T. H., 1970. The benthic ecology of Loch Linnhe and Loch Eil, a sea-loch system on the west coast of Scotland. I. The physical environment and distribution of macrobenthic fauna. $-\mathrm{J}$. exp. mar. Biol. Ecol. 5, 1-34.

Pearson, T. H., 1971a. Studies on the ecology of the macrobenthic fauna of Lochs Linnhe and Eil, west coast of Scotland. II. Analysis of the macrobenthic fauna by comparison of feeding groups. Vie Milieu (Suppl.) 22, 53-91.

Pearson, T. H., 1971b. The benthic ecology of Loch Linnhe and Loch Eil, a sea-loch system on the west coast of Scotland. III. The effect on the benthic fauna of the introduction of pulp mill effluent. - J. exp. mar. Biol. Ecol. 6, 211-233.

Pearson, T. H., 1975. The benthic ecology of Loch Linnhe and Loch Eil, a sea-loch system on the west coast of Scotland. IV. Changes in the benthic fauna attributable to organic enrichment. -J. exp. mar. Biol. Ecol. 20, 1-41.

Pearson, T. H. \& Rosenberg, R., 1976. A comparative study of the effects on the marine environment of wastes from cellulose industries in Scotland and Sweden. - Ambio 5, 77-79.

Poole, N. J., Parkes, R. J. \& Wildish, D. J., 1977. Reaction of estuarine ecosystems to effluent from pulp and paper industry. - Helgoländer wiss. Meeresunters. 30, 622-632. 
Reise, K., 1977. Predation pressure and community structure of an intertidal soft-bottom fauna. In: Biology of benthic organisms Ed. by B. F. Keegan, P. O. Ceidigh \& P. J. S. Boaden. Pergamon Press, Oxford, 513-519.

Rosenberg, R., 1972. Benthic faunal recovery in a Swedish fjord following the closure of a sulphite pulp mill. - Oikos 23, 92-108.

Rosenberg, R., 1973a. Recovery of the littoral fauna in Saltkallefjord subsequent to discontinued operations of a sulphite pulp mill. - Thalassia jugosl. 7, 341-351.

Rosenberg, R., 1973b. Succession in benthic macrofauna in a Swedish fjord subsequent to the closure of a sulphite pulp mill. - Oikos 24, 244-258.

Stockner, J. G. \& Cliff, D. D., 1976. Effects of pulp mill effluents on phytoplankton production in coastal marine waters of British Columbia. - J. Fish. Res. Bd Can. 33, 2433-2442.

Wharfe, J. R., 1975. A study of the intertidal macrofauna around the BP refinery (Kent) Limited. Environ. Pollut. 9, 1-12. 